\title{
1 A systematic review of enteric pathogens and antibiotic resistance genes in outdoor urban
}

2 aerosols

3

4 Olivia Ginn ${ }^{1}$, Sarah Lowry ${ }^{2}$, Joe Brown ${ }^{3}$

5

$6{ }^{1}$ Department of Civil \& Environmental Engineering \& Earth Science, University of Notre Dame, 156

7 Fitzpatrick Hall, Notre Dame, IN 46556, USA

$8 \quad{ }^{2}$ Department of Civil and Environmental Engineering, Stanford University, Stanford, California, United

9 States

$10{ }^{3}$ Deparment of Environmental Sciences and Engineering, Gillings School of Global Public Health, 11 University of North Carolina, Chapel Hill, North Carolina, 27599, United States

12

13 *Correspondence to: (Primary) Dr. Joe Brown, Department of Environmental Sciences and Engineering,

14 University of North Carolina, 135 Dauer Drive, Chapel Hill, NC, 27599, USA. Tel: 919360 8752. Email:

15 joebrown@unc.edu. ORCID: 0000-0002-5200-4148. (Secondary) Dr. Olivia Ginn, Department of Civil \&

16 Environmental Engineering \& Earth Science, University of Notre Dame, 156 Fitzpatrick Hall, Notre

17 Dame, IN, 46556, USA. oginn@nd.edu. ORCID: 0000-0002-0109-0699 


\section{ABSTRACT}

27 Aerosol transport of enteric microbiota including fecal pathogens and antimicrobial resistance genes

28 (ARGs) has been documented in a range of settings but remains poorly understood outside indoor

29 environments. We conducted a systematic review of the peer-reviewed literature to summarize evidence

30 on specific enteric microbiota including enteric pathogens and ARGs that have been measured in aerosol

31 samples in urban settings where the risks of outdoor exposure and antibiotic resistance (AR) spread may

32 be highest. Following PRISMA guidelines, we conducted a key word search for articles published within

33 the years 1990-2020 using relevant data sources. Two authors independently conducted the keyword

34 searches of databases and conducted primary and secondary screenings before merging results. To be

35 included, studies contained extractable data on enteric microbes and AR in outdoor aerosols regardless of

36 source confirmation and reported on qualitative, quantitative, or viability data on enteric microbes or AR.

37 Qualitative analyses and metric summaries revealed that enteric microbes and AR have been consistently

38 reported in outdoor aerosols, generally via relative abundance measures, though gaps remain preventing

39 full understanding of the role of the aeromicrobiological pathway in the fate and transport of enteric

40 associated outdoor aerosols. We identified remaining gaps in the evidence base including a need for broad

41 characterization of enteric pathogens in bioaerosols beyond bacterial genera, a need for greater sampling

42 in locations of high enteric disease risk, and a need for quantitative estimation of microbial and nucleic

43 acid densities that may be applied to fate and transport models and in quantitative microbial risk

44 assessment.

45

46 KEYWORDS

47 enteric pathogens, antibiotic resistance, bioaerosols, urban air, public health, sanitation 


\section{FUNDING}

53 This study was funded by the National Science Foundation under grant number 1653226. This funding

54 source had no role in the design of this study and had no role during its execution, analyses, interpretation 55 of the data, or decision to submit results.

\section{$57 \quad 1.0$ INTRODUCTION}

58 Studies in high-risk outdoor settings in the USA and in other high-income countries have revealed that

59 bioaerosols containing enteric (intestinal) microbes are common where concentrated human or animal

60 fecal waste and one or more mechanisms for aerosolization co-occur. Presence of enteric microbes in

61 aerosols has been best characterized in ambient air surrounding specific point and area sources such as

62 wastewater treatment plants ${ }^{1-12}$ land applied biosolids, ${ }^{13-23}$ composting facilities, ${ }^{24,25}$ meat markets, ${ }^{26}$

63 urban areas, ${ }^{9,27,28}$ landfills, ${ }^{29,30}$ and concentrated animal feeding operations. ${ }^{31-33}$ In many of these cases,

64 adequate waste disposal technology exists but bioaerosols containing these targets are consistently

65 detected. A growing body of literature acknowledges the potential risk accompanying enteric microbes

66 and antibiotic resistant (AR) enteric microbes in aerosols where a source is suspected or confirmed.

67 Studies of exposure to these point and area sources typically assess nearby residents ${ }^{20,34}$ or facility

68 workers ${ }^{35,36}$ who might be at greatest risk.

70 Settings less well characterized in the context of enteric pathogens and associated AR are ambient urban

71 outdoor environments where sources may be diffuse and related to generally inadequate or poorly

72 performing environmental controls or waste management ${ }^{37,38}$. Establishing and maintaining effective and

73 sustainable infrastructure to improve population health in cities is becoming increasingly difficult due to

74 factors including accelerating urbanization and densification, climate change and its effects on

75 infrastructure, and financing constraints; these and other limiting factors are most acute in low- and

76 middle-income countries (LMICs). Information on ambient fluxes of enteric pathogens and AR in cities

77 lacking good waste management is needed, targeting settings with potentially elevated exposure risks and 
78 AR spread. Cities in high-income countries (HICs) are not generally considered high risk for exposure to

79 enteric pathogens via sanitary deficits: human excreta is typically directed into covered or underground

80 wastewater infrastructure, creating a separation between humans and their waste to interrupt transmission

81 of enteric infections via well understood pathways. ${ }^{39}$ However, in LMICs where wastewater and biosolids

82 present greater risks due to the high number of circulating infectious diseases - and poorly controlled

83 antibiotic stewardship ${ }^{40}$ - in the population contributing waste and the presence of unsequestered waste in

84 closer proximity to more people, risk may be higher for exposure through inhalation or ingestion,

85 including indirectly following surface deposition of bioaerosols. ${ }^{41-44}$ Recent studies have described novel

86 detections along with aeromicrobiological transport of enteric pathogens in aerosols, drawing attention to

87 this pathway in the context of disease transmission ${ }^{44,45}$ and AR emergence and dissemination. In order to

88 advance understanding of the current and potential impact of enteric pathogens and AR in bioaerosols in

89 high-risk settings, we seek to describe the rich emerging literature on this topic and identify gaps in

90 evidence. Therefore, we conducted a systematic review of published estimates reporting detections of

91 enteric microbiota and ARs in cities.

\section{$93 \quad 2.0$ METHODS}

94 We followed PRISMA guidelines for reporting of systematic reviews ${ }^{46}$ as recommended in the WHO 95 Handbook for Guideline Development, ${ }^{47}$ including all meta-data from searches per the recommended 96 PRISMA flow diagram. We pre-specified our methods (https://osf.io/6Q7E9/) and provide a full list of

97 preferred reporting items in Supplemental Material. Our outcomes included any report of enteric microbe

98 (bacteria, virus, protozoa) or any ARG from pre-determined lists meeting our site criteria, from either

99 qualitative or quantitative studies assessing their presence. Site criteria were: urban areas with either no

100 known source or a point or area source related to concentrated animal feeding operations (CAFOs),

101 wastewater treatment plants (WWTPs), composting facilities, landfills or other identified source. 

academic peer-reviewed literature including: ISI Web of Science, PubMed, SCOPUS, EBSCOhost, and

106 Science.gov. We conducted additional searches in ProQuest Dissertations and Theses Global.

108 We compiled the string of keywords for searching the literature databases from our own knowledge of the

109 topic, and from suggestions by experts and existing reviews in related topics. ${ }^{48-52}$ These search terms were

110 refined based on synonyms, abbreviations, and alternate spellings and were expanded and adjusted as

111 initial searches were performed. Searches were in the form of a one line string that included all fields

112 from the scope (e.g., aerosol, extramural, urban...), pathogens (e.g., enteric, fecal indicator,

113 adenovirus...), exposures (e.g., inhalation, ingestion, viable...), mechanisms (e.g., aerosolization,

114 bubbles, aeration...), sampling methods (e.g., impaction, impinger, filter...), AR associated (e.g., intIl,

115 tet $A, q n r B \ldots$ ), and antibiotics (e.g., tetracycline, fluoroquinolones, multidrug resistance...). Search strings

116 used "or" and "and" statements to include multiple fields such as "fecal indicator bacteria OR FIB" AND

117 "bioaerosol OR ambient OR air OR aerosol OR airborne". The full search string is detailed in

118 Supplemental Material.

120 Two authors independently conducted the keyword searches in each database and compiled findings in

121 Zotero (Version 5·0·96). After deduplication of search results, the authors each conducted an initial

122 screening based on titles and abstracts of papers. Papers passed the initial screening if the title or abstract

123 suggested relevance to the keywords in the search. The full text of papers that passed initial screening

124 were reviewed independently by the two authors if papers were: (1) published in English; (2) published

125 from the 1990-2020; and (3) published or accepted for publication in a peer-reviewed journal, refereed

126 conference proceedings, government or multilateral document, thesis or dissertation, book, or other

127 document appearing on indexed databases we identified; (4) contained extractable data on enteric

128 microbes including pathogens and AR in outdoor bioaerosols; (5) contained data on targets that could be

129 related to no source, a specific point source, or an area source but must have been from an urban site; and 
(6) reported on qualitative (presence/absence), quantitative (culture or PCR-based), or viability (culture)

131 data that was sufficient for interpretation within the three aforementioned groups.

133 After independent searches, we consulted and compared our findings to achieve consensus on inclusion.

134 For any dissent on inclusion of a paper, a third party was consulted for discussion before again reaching a 135 consensus decision on inclusion. Backward searches examined the references, authors and contributors, 136 and keywords identified in the literature resulting from the initial keyword searches. Forward searches

137 examined articles not initially identified that have referenced literature resulting from the initial keyword 138 searches.

\subsection{Data collection and analysis}

141 For each study, data were extracted and recorded; the full compilation is included in Supplemental

142 Material. We recorded document identifiers such as authors, publication year, document type, and

143 whether the document was found through initial, backward, or forward searches. We categorized

144 documents meeting inclusion criteria first by subject, either AR or enteric microbes detection. Some

145 publications reported both. We then categorized these by analysis method: culture, PCR, or sequencing.

147 We extracted and recorded general study characteristics such as location, sampling method, sample size,

148 and intended targets. Depending on the category, we recorded qualitative, quantitative, and semi-

149 quantitative data, indicating relevant targets and results within the scope of our review. A formal meta-

150 analysis of the disparate findings was not deemed possible given the limited evidence on this topic and

151 the wide diversity of methods employed in measurement in this emerging area. Therefore, we synthesized

152 review data through categorization and descriptive summary, a common approach when quantitative

153 meta-analysis is not possible, ${ }^{53}$ revealing both a broad description of what is known as well as identifying 154 gaps requiring further evidence. 
medRxiv preprint doi: https://doi.org/10.1101/2021.10.26.21265483; this version posted February 10, 2022. The copyright holder for this preprint

(which was not certified by peer review) is the author/funder, who has granted medRxiv a license to display the preprint in perpetuity.

All rights reserved. No reuse allowed without permission.

\section{$156 \quad 3.0$ RESULTS}

\section{$157 \quad 3.1$ Search results}

158 Searches returned 1226 publications from 6 databases. Upon removal of duplicates, initial screening of

159 the title and abstract, and full text screening, 52 publications met search criteria. Forward and backward

160 searches yielded additional publications for a total of 101 to be included in this review.

161 
medRxiv preprint doi: https://doi.org/10.1101/2021.10.26.21265483; this version posted February 10, 2022. The copyright holder for this preprint (which was not certified by peer review) is the author/funder, who has granted medRxiv a license to display the preprint in perpetuity.

All rights reserved. No reuse allowed without permission.

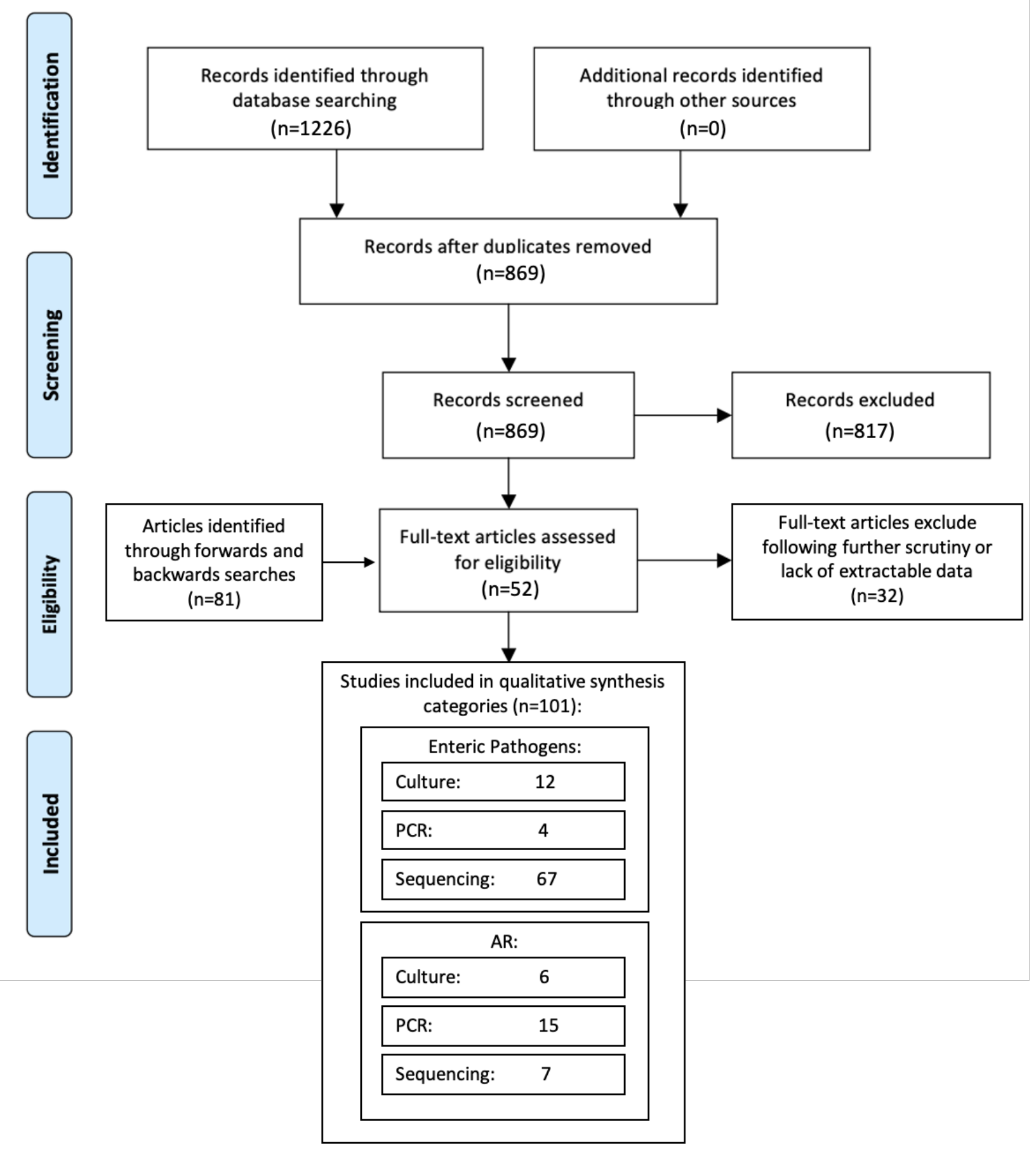

163 Figure 1. Modified PRISMA flow diagram applied to our systematic review process.

164

$165 \quad 3.2$ Study characteristics 
medRxiv preprint doi: https://doi.org/10.1101/2021.10.26.21265483; this version posted February 10, 2022. The copyright holder for this preprint (which was not certified by peer review) is the author/funder, who has granted medRxiv a license to display the preprint in perpetuity.

All rights reserved. No reuse allowed without permission.

Of the 101 studies we included, ten reported multiple data types or multiple subjects and methodologies,

167 reflected in Figure 1 and Table 1. Table 1 details the intended targets for each study. The full table listing

168 each publication by first author and year can be found in Supplemental Material. Overall, 28\% of the

169 studies identified in this systematic review reported on AR related data and $82 \%$ reported on enteric

170 microbe related data (1\% reported both). We observed sequencing to be the most frequent analysis

171 method, accounting for $75 \%$ across all studies. A majority of studies took place in upper-middle and high-

172 income countries ( $\mathrm{n}=89$ ), with only ten studies based in LMICs including India, Mali, Bolivia, and

173 Vietnam (Figure 2). A few studies collected data from both income categories. China accounted for

174 almost $50 \%$ of all studies. Only $9 \%$ of studies were published since 2010.

175

176 Bioaerosol sampling can typically be categorized by three different methods: filtration, impaction, and

177 impingement. In our review, the majority of studies employed filtration to collect bioaerosol samples

178 ( $\mathrm{n}=60$ studies). Filtration was followed by active impaction $(\mathrm{n}=28)$, impingement $(\mathrm{n}=10)$, and passive

179 impaction via gravitational settling $(\mathrm{n}=8)$. Some studies used multiple methods, often when performing

180 culture-dependent analyses in addition to culture-independent analyses.

Table 1: Studies included in the review by categories of target type (antibiotic resistance related or

183 enteric microbe related) and by data type and analysis method. The intended targets are also categorized.

\begin{tabular}{|c|c|c|c|c|}
\hline & Data Type & Method & Count & Intended Targets \\
\hline \multirow{6}{*}{ AR } & Qualitative & PCR & 1 & ARGs specified a priori \\
\hline & \multirow{2}{*}{ Quantitative } & Culture & 6 & $\begin{array}{l}\text { AR associated microbes } \\
\text { specified } a \text { priori }\end{array}$ \\
\hline & & PCR & 13 & \multirow{2}{*}{ ARGs specified a priori } \\
\hline & \multirow{2}{*}{$\begin{array}{l}\text { Semi- } \\
\text { quantitative }\end{array}$} & PCR & 1 & \\
\hline & & sequencing & 7 & Any ARGs \\
\hline & Total AR & & 28 & \\
\hline \multirow{5}{*}{ Enteric } & Qualitative & Culture & 2 & \multirow{2}{*}{$\begin{array}{l}\text { Enteric microbes specified } a \\
\text { priori }\end{array}$} \\
\hline & \multirow{2}{*}{ Quantitative } & Culture & 10 & \\
\hline & & PCR & 2 & \multirow{2}{*}{$\begin{array}{l}\text { Enteric microbe specified } a \\
\text { priori }\end{array}$} \\
\hline & \multirow{2}{*}{$\begin{array}{l}\text { Semi- } \\
\text { quantitative }\end{array}$} & PCR & 1 & \\
\hline & & sequencing & 68 & All microbial communities \\
\hline
\end{tabular}


medRxiv preprint doi: https://doi.org/10.1101/2021.10.26.21265483; this version posted February 10, 2022. The copyright holder for this preprint (which was not certified by peer review) is the author/funder, who has granted medRxiv a license to display the preprint in perpetuity.

All rights reserved. No reuse allowed without permission.

\begin{tabular}{|c|c|}
\hline Total Enteric & 83 \\
\hline Repeats & 10 \\
\hline TOTAL & 101 \\
\hline
\end{tabular}

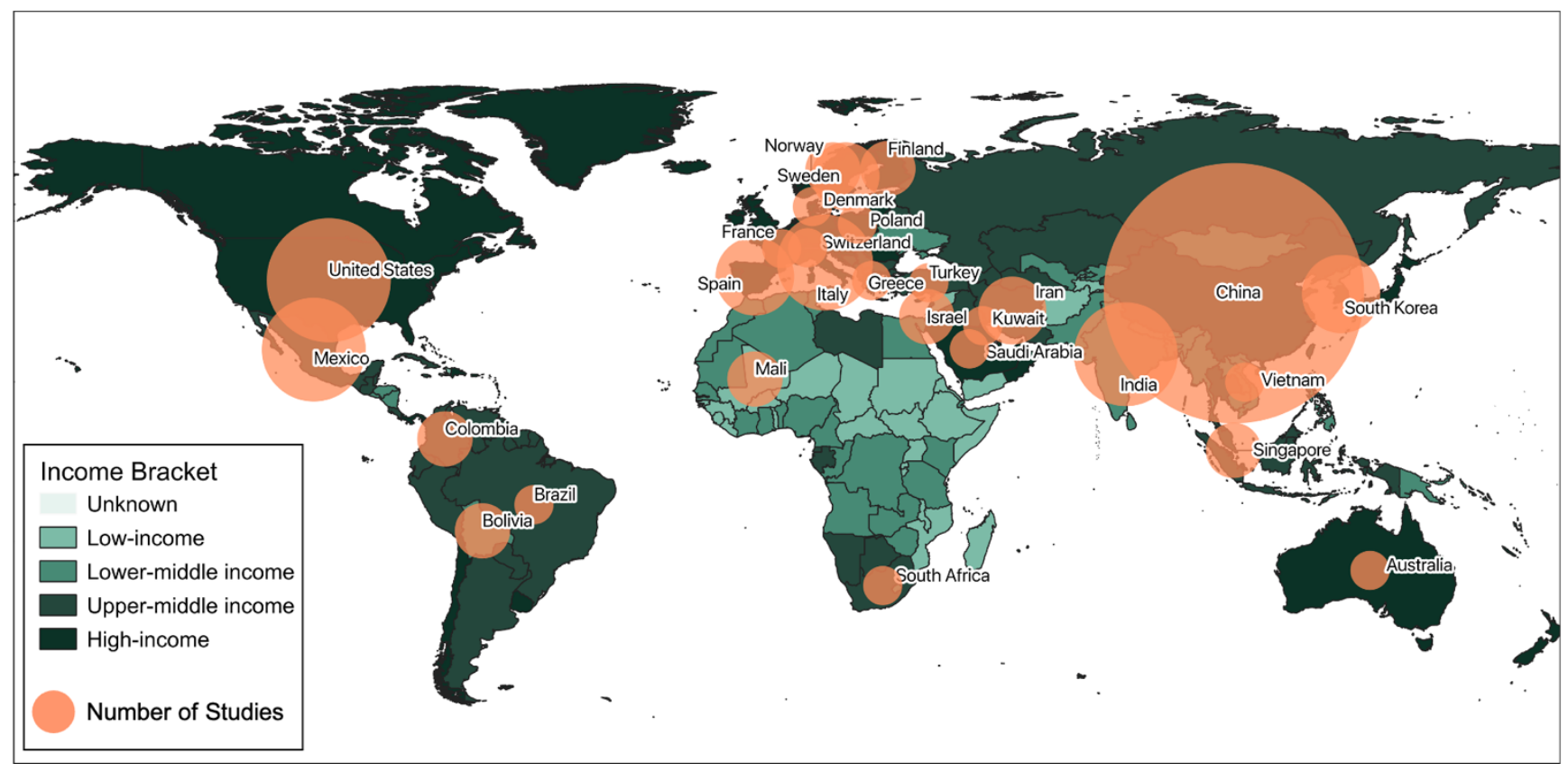

Figure 2. Total number of studies by country of measurement, with circle size proportional to number of studies ( $\mathrm{n}=1$ to 44 in China).

\subsection{Results from specific studies}

\section{Enteric microbes}

192 Overall, studies reporting on enteric microbe detection in bioaerosols in urban settings targeted a limited 193 range of microbes, focusing on well-established fecal indicators and in the case of detection via culture, 194 easily culturable bacteria such as Enterococcus, Enterobacter and Escherichia genera. ${ }^{54}$ One study 195 reported detection through culture of Yersinia enterocolitica, Salmonella spp. and others in Chinese live 196 poultry markets in urban Tai'an, ${ }^{55}$ though in general the city includes extensive sanitation infrastructure 197 throughout. ${ }^{56}$ For quantitative PCR (qPCR), reported enteric microbes included pathogens as well as 198 possibly commensal enteric bacteria (Escherichia coli, Enterococcus spp., Enterobacter spp., Yersinia 
199 enterocolitica, and Salmonella spp.) ${ }^{54,57}$ and enteric virus (human adenovirus, human enterovirus, and

200 human rotavirus). ${ }^{58-60}$

201

202 A majority of studies assessed overall microbial communities through sequencing, typically employing

203 16S rRNA. Of these 67 studies, nine classified the population taxonomy to order level, ${ }^{61-68}$ eight

204 classified to family level, ${ }^{69-74} 37$ classified to genus, ${ }^{51,64,75-109} 12$ classified to species ${ }^{28,54,59,83,98,110-118}$ and

205 only one identified a strain-specific ${ }^{119}$ species (Figure 3). When classified to order or family,

206 Enterobacteriales and Enterobacteriaceae (respectively) were detected as less than 1\% of the bacterial

207 community. However, one study detected the families Campylobacteraceae (Arcobacter) and

208 Helicobacteraceae ${ }^{70}$ and another study detected the orders Clostridiales and Campylobacterales. ${ }^{65}$

209 Escherichia or Escherichia-Shigella, Enterococcus and Clostridium were detected most frequently at the

210 genus level. Vibrio, Campylobacter, Yersinia, Klebsiella, and Aeromonas were also detected in a few

211 studies at the genus level. Enteric microbes detected at the genus or species level through sequencing

212 included Aeromonas spp., Enterobacter spp., Escherichia coli, Enterococcus faecium, Clostridium spp.,

213 Vibrio parahaemolyticus, Salmonella enterica, Campylobacter coli, Yersinia enterocolitica, Shigella spp.,

214 Klebsiella pneumonia, and Escherichia fergusonii. One study in a tropical urban setting identified,

215 through sequencing, the pathogenic strain of Escherichia coli O157:H7. ${ }^{119}$ 


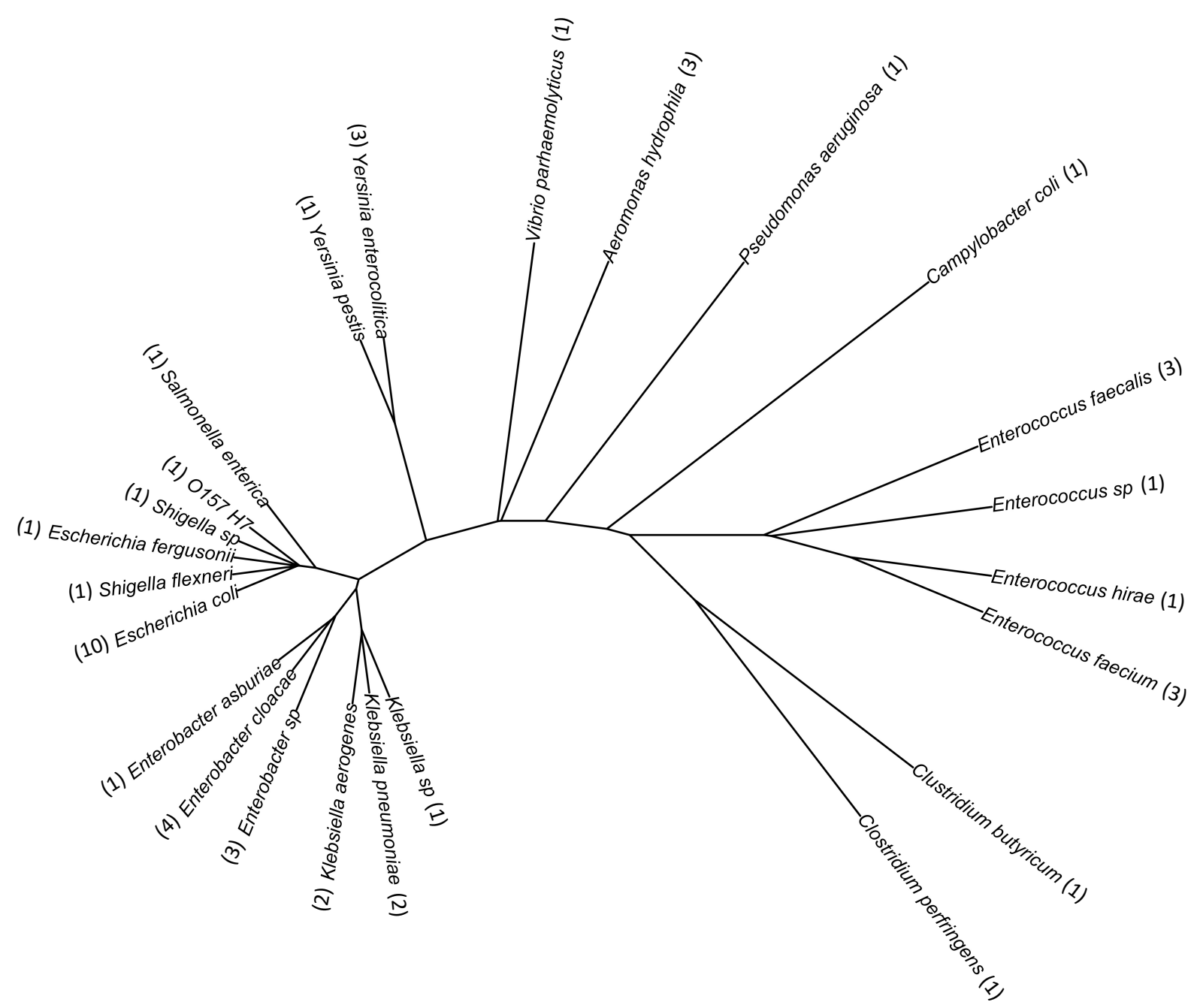

217 Figure 3: Taxonomic organization of enteric bacterial targets detected in studies included in the review. 218 The number of manuscripts in which bacteria were detected are included in parenthesis where relevant.

220 The review revealed only three studies assessing enteric viruses in urban outdoor aerosols. Viral

221 detections include human adenovirus and human adenovirus $\mathrm{C}$; enterovirus $\mathrm{A}, \mathrm{B}$ and $\mathrm{C}$; and rotavirus $\mathrm{A}^{58-}$

$222{ }^{60}$ Generally, the range of enteric microbes identified in bioaerosols in urban settings is small and we see 
medRxiv preprint doi: https://doi.org/10.1101/2021.10.26.21265483; this version posted February 10, 2022. The copyright holder for this preprint (which was not certified by peer review) is the author/funder, who has granted medRxiv a license to display the preprint in perpetuity.

All rights reserved. No reuse allowed without permission.

223 an even smaller range represented among the culturable targets across studies. A complete breakdown by

224 taxonomic classification of enteric microbes detected in the reviewed studies by all methods is in Table 2.

225

226 Table 2: Number of studies reporting enteric microbe (commensal and pathogenic) detections broken 227 down by taxonomic classification.

\begin{tabular}{|c|c|c|c|c|c|c|c|c|c|}
\hline \multicolumn{10}{|c|}{ NUMBER OF STUDIES REPORTING VIRAL DETECTIONS } \\
\hline & & & & Genus & & Species & & & \\
\hline & & & & Human adenovirus & 1 & enterovirus A* & 1 & & \\
\hline & & & & & & enterovirus B* & 1 & & \\
\hline & & & & & & enterovirus $\mathrm{C}^{*}$ & 1 & & \\
\hline & & & & & & rotavirus $\mathrm{A}^{*}$ & 1 & & \\
\hline & & & & & & Human adenovirus $\mathrm{C}$ & 1 & & \\
\hline \multicolumn{10}{|c|}{ NUMBER OF STUDIES REPORTING BACTERIAL DETECTIONS } \\
\hline \multicolumn{2}{|l|}{ Order } & \multicolumn{2}{|l|}{ Family } & \multicolumn{2}{|l|}{ Genus } & \multicolumn{2}{|l|}{ Species } & Strain & \\
\hline Enterobacterales & 9 & Enterobacteriaceae & 8 & Enterococcus & 22 & Escherichia coli & 13 & Escherichia coli $0157: \mathrm{H}^{*}$ & 1 \\
\hline Clostridiales & 1 & Campylobacteraceae & 1 & Enterobacter & 19 & Enterobacter aerogenes & 1 & & \\
\hline \multirow{18}{*}{\multicolumn{2}{|c|}{ Campylobacterales 2}} & Helicobacteraceae & 1 & Salmonella & 5 & Enterobacter asburiae & 1 & & \\
\hline & & & & Escherichia & 12 & Enterococcus faecalis & 3 & & \\
\hline & & & & Clostridium & 8 & Enterococcus hirae & 1 & & \\
\hline & & & & Vibrio & 2 & Yersinia pestis* & 1 & & \\
\hline & & & & Campylobacter & 3 & Enterobacter cloacae & 4 & & \\
\hline & & & & Yersinia* & 3 & Enterococcus faecium & 4 & & \\
\hline & & & & Aeromonas & 2 & Aeromonas hydrophila & 3 & & \\
\hline & & & & Shigella & 5 & Pseudomonas aeruginosa & 1 & & \\
\hline & & & & Escherichia/Shigella & 15 & Yersinia enterocolitica* & 3 & & \\
\hline & & & & & & Escherichia fergusonni & 2 & & \\
\hline & & & & & & Clostridium butyricum & 1 & & \\
\hline & & & & & & Clostridium perfringens & 1 & & \\
\hline & & & & & & Vibrio parahaemolyticus & 1 & & \\
\hline & & & & & & Salmonella enterica* & 1 & & \\
\hline & & & & & & Campylobacter coli* & 1 & & \\
\hline & & & & & & Enterobacter coli & 1 & & \\
\hline & & & & & & Enterobacter hormaechei & 1 & & \\
\hline & & & & & & Shigella flexneri* & 1 & & \\
\hline
\end{tabular}

\subsection{Antibiotic resistance}

231 We identified fewer studies reporting on antibiotic resistant bacteria and antibiotic resistance encoding

232 genes (ARGs) in bioaerosols $(\mathrm{n}=28)$. Using selective culture and often using disk diffusion methods, ${ }^{120}$

233 studies reported viable bacterial resistance to a broad range of antibiotic groups also highlighted on the

234 US Food and Drug Administration's, National Antimicrobial Resistance Monitoring System as existent or

235 emerging threats, ${ }^{121}$ Some of these groups include 
$236 \beta$--lactams (penicillins, cephalosporins and carbapenems), tetracyclines, quinolones, aminoglycosides,

237 sulfonamides, and phenicols. Through $\mathrm{qPCR}$, a wide range of AR related genetic targets have been

238 detected in urban aerosols such as antibiotic resistance genes (ARGs), mobile genetic elements (MGEs)

239 encoding horizontal gene transfer ability, or mobile integrons (MIs) encoding the ability to undergo

240 recombination and functional conversion of ARGs (Table 3). ${ }^{122-124}$ However, of the studies that detected

241 ARGs in bioaerosols via PCR, 79\% took place in upper-middle and high-income countries. 
Table 3: Antibiotic Resistance related categorization with number of studies citing each target (at various levels) in parenthesis.

\begin{tabular}{|c|c|c|c|c|}
\hline & $\begin{array}{l}\text { Drug } \\
\text { Mechanism }\end{array}$ & Drug Class & Resistance genes & Drug \\
\hline \multirow{9}{*}{ Antibiotics } & \multirow{5}{*}{$\begin{array}{l}\beta- \\
\operatorname{lactams}(2)\end{array}$} & Multiple Classes & $\begin{array}{l}\text { SHV (2), TEM (5), ampC (1), AMP (1), OXA (1), IMP (1), } \\
\text { OXA-212 (1), OXA-278 (1), OXA-360 (1), VEB (1), GES (1), } \\
\text { TEM-193 (1), NDM-1 (2) }\end{array}$ & --- \\
\hline & & penem (1) & CME3 (1), mecA (4), PBP-2x (1) & $\begin{array}{l}\text { piperacillin (1) } \\
\text { penicillin (2) } \\
\text { ampicillin (3) } \\
\text { oxacillin (1) } \\
\text { carbenicillin (1) } \\
\text { cloxacillin (1) } \\
\text { amoxicillin (2) } \\
\text { amoxicillin/clavulanic acid } \\
(1)\end{array}$ \\
\hline & & cephalosporin & CTX-1 (1), CTX-M1 (2), CTX-M-32 (1) & $\begin{array}{l}\text { cefotaxime }(2) \\
\text { ceftazidime }(1) \\
\text { cephalorodine }(1)\end{array}$ \\
\hline & & cephamycin & CMY (1), CMY-2 (4) & --- \\
\hline & & carbapenem & --- & $\begin{array}{l}\text { imipenem (3) } \\
\text { meropenem (1) }\end{array}$ \\
\hline & \multirow{3}{*}{$\begin{array}{l}\text { Folate } \\
\text { Synthesis } \\
\text { (1) }\end{array}$} & sulfonamide & sul1 (10), sul2 (6), sul3 (4) & --- \\
\hline & & diaminopyrimidine & dfrA12 (1) & --- \\
\hline & & $\begin{array}{l}\text { diaminopyrimidine/sulfonamide } \\
\text { combination }\end{array}$ & --- & $\begin{array}{l}\text { sulfamexoxazole- } \\
\text { trimethoprim (1) }\end{array}$ \\
\hline & $\begin{array}{l}\text { MDR } \\
\text { efflux } \\
\text { pump (1) }\end{array}$ & Multiple Classes & qacEdelta1-02 (1), emrD (1) & --- \\
\hline
\end{tabular}




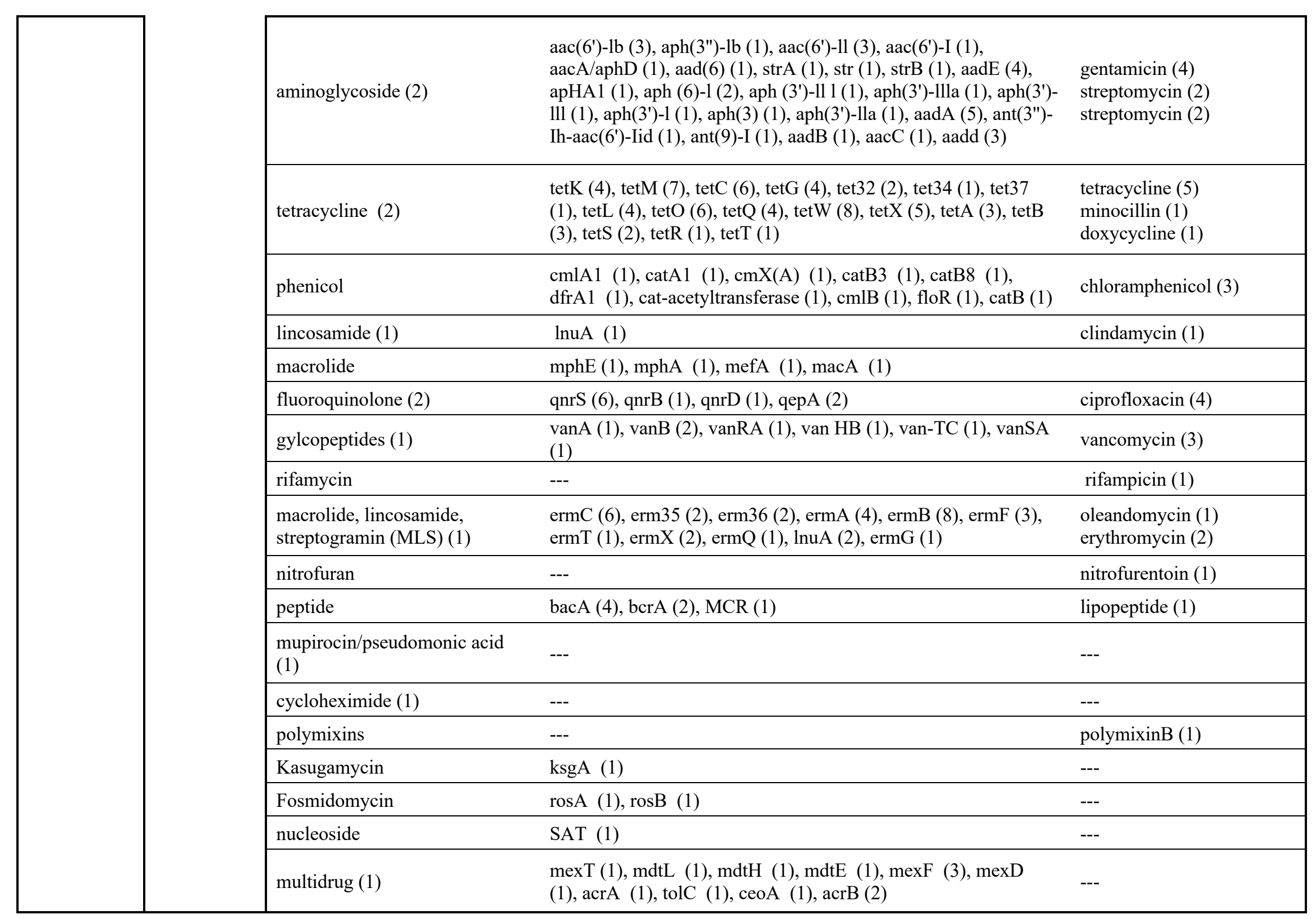


Mobile Genetic Elements

intI1 (7), tnpA (2), ICR3 (1), IS613 (1), tnpA-02 (1), tnpA-04 (1) 


\subsection{DISCUSSION}

245 Results of this systematic review suggest that fecal signatures are present in ambient urban air across the

246 globe, along with evidence suggesting aerosols may play a role in urban AR spread. Notably, studies

247 conducted in cities in LMICs show a broad and diverse range of airborne microbial gene targets of

248 possibly human fecal origin, potentially related to sanitation infrastructure deficits ${ }^{125}$ that permit

249 uncontained waste flows in densely populated urban areas ${ }^{44}$. However, the results also reveal large gaps in

250 the characterization and detection of important enteric microbes and AR in bioaerosols in ambient urban

251 air. An especially concerning gap is that LMICs make up a minority of all study locations within the

252 scope of this review, despite the fact that cities in these countries may be characterized by inadequate

253 sanitation infrastructure and high population density, leading to widespread fecal contamination and

254 disproportionately bearing the global burden of diarrheal disease, the cause of 1.8 million deaths

255 worldwide in $2017 .{ }^{126}$ Given widespread carriage and shedding of important enteric pathogens, poor

256 containment of sanitary waste near population centers, and the limited evidence that enteric pathogen-

257 associated nucleic acids are widely present in aerosols, these sites should be an explicit focus of future

258 monitoring efforts to understand the extent and implications of fecal microbe transport in aerosols.

260 Studies that do assess enteric microbes and AR are dominated by quantal (presence/absence) or semi-

261 quantitative data obtained through sequencing. Such estimates target abundance in terms of the microbial

262 community within each sample, as opposed to the environment in which the communities exist. While

263 sequencing is useful in broadly characterizing and understanding infectious diseases and microbial

264 communities in general, it is less useful in the context of transport phenomena and exposure

265 measurements without additional contextual data, typically quantitative measurements that report density

266 of specific genes or microbes per unit volume or mass. ${ }^{127}$ In the case of whole-genome sequencing,

267 selection bias may be introduced if the microorganisms chosen for analysis are not representative of the

268 broader population in the sample. ${ }^{127}$ When entire communities are sequenced, selection bias is resolved to

269 a degree but additional shortcomings remain or are introduced such as quality control, quantification 
270 limitations, high limits of detection or lack of comparability across other methods and studies. ${ }^{128}$

271 Furthermore, characterizing specific genes such as those encoding antibiotic resistance requires increased

272 sequencing depth which is not always possible with low concentration samples like bioaerosols. ${ }^{129}$ The

273 studies that do quantitatively assess gene targets of enteric microbes $(n=t w o)$ and AR $(n=14)$ in

274 bioaerosols provide more context, assessing targets in relation to the environmental media in which they

275 are found as opposed to in relation to other targets present. Importantly, many of the most critical AR

276 pathogens globally are known to be enriched in fecal wastes, including E. coli, Klebsiella spp., and

277 Pseudomonas aeruginosa. ${ }^{130}$ All of these studies leverage real-time qPCR which is limited to

278 interpretation based on standard curves as opposed to absolute quantification which allows for lower

279 limits of detection ${ }^{131}$. While molecular detections are important in characterizing enteric microbes

280 including pathogens of concern, detection of microbe-specific nucleic acid sequences do not indicate

281 viability. Co-culture with fecal indicator bacteria most often detected in these studies (E. coli,

282 Enterobacter sp., or Enterococcus sp.) may indirectly indicate potential viability of other microbes;

283 vegetative bacteria are typically a conservative proxy for pathogen viability since they are readily

284 inactivated in aerosols ${ }^{132,133}$. The combination of absolute quantification with an expansion of viability

285 detection methods would contribute to advancing understanding of the potential public health relevance

286 of this poorly understood pathway of transmission. ${ }^{131}$ The need for data characterizing aerosol transport

287 of enteric pathogens and AR is most critical in settings where the risks of sanitation-related infections and

288 AR spread are highest, typically LMICs where economic resources and laboratory capacity may be most

289 limited. Although high-volume sample collection and methodologically sophisticated pathogen assays

290 may often be unavailable in such settings, affordable and accessible detection of culturable fecal indicator

291 bacteria and phenotypic resistance testing can provide valuable insight into potential health impacts for

292 exposed populations. ${ }^{58,134,135}$

293

294 Studies included in this review reporting on enteric microbes including pathogens in bioaerosols in urban

295 settings targeted a limited range of enteric microbes, with many studies (38\%) reporting detection of 
commonly used fecal indicator bacteria (Escherichia coli and Enteroccocus). Only one study in a tropical

297 urban setting identified, through sequencing, the pathogenic strain of Escherichia coli, O157:H7 (EHEC)

298 yielding a limited data pool that excludes other strains such as ETEC, EPEC and others that were

299 responsible for over 60,000 deaths across the globe in $2016 .{ }^{136}$ Furthermore, though Campylobacter coli

300 was detected in one study through sequencing at the species level, other pathogenic strains of

301 Campylobacter remain uncharacterized in bioaerosols, even though it was responsible for 75,000

302 diarrheal deaths worldwide in $2016 .{ }^{136}$ Overall, the majority of enteric bacteria and viruses reported in

303 the studies targeted and detected commensal enteric microbiota or opportunistic pathogens that typically

304 only cause disease in immunocompromised individuals. Recent evidence reveals the growing relevance of

305 opportunistic pathogens in clinical settings, particularly in the context of their low susceptibility to

306 antibiotics and environmental origins ${ }^{137}$. Frank pathogens, which cause disease even in immunocompetent

307 individuals are less represented in the review, making up less than half (39\%) of all unique microbes

308 reported at the strain and species levels across all studies (Table 2).

310 Few studies targeted and detected enteric viruses, even though fecal microbes are present and often are

311 co-occurring with enteric viruses ${ }^{44,138-140}$. Viruses may be highly mobile in aerosols, but would not be

312 captured in 16S rRNA sequencing that represents the bulk of analytical methods used in bioaerosols

313 analysis. The available evidence from our review and other emerging evidence ${ }^{44}$ suggests that enteric

314 viruses are important potential targets in urban aerosols, particularly norovirus given its well documented

315 transport in aerosols ${ }^{141-144}$. Of the studies that employed methods that would be suited to the detection of 316 enteric viruses ( 6 out of 101 covered in this review), 33\% $(n=2)$ identified them, including detections of 317 human enterovirus, human rotavirus, and human adenovirus (Table 2).

320 No study included in our review targeted or reported enteric protozoans in bioaerosols in an urban setting, 321 so an absence of evidence on detection of this class of enteric microbes should not be interpreted as 
322 evidence that they are not present in aerosols. These microbes tend to be larger in size $(5-15 \mu \mathrm{m})$ and

323 therefore experience rapid settling, and so may be of less interest in aerosol transport modeling, however.

324 Despite this, some evidence suggests they could be widely detected in aerosols and may therefore merit

325 further study. A study from rural Mexico detection of Cryptosporidium and Giardia in air samples via

326 microscopy. ${ }^{45}$ A study published following our review reported detection of Giardia duodenalis and

327 Cryptosporidium spp. near open sewers in both urban La Paz, Bolivia and Kanpur, India via qPCR, with

328 G. duodenalis detected in $22 \%$ of samples in La Paz and $18 \%$ of samples in Kanpur. ${ }^{44}$ In this study,

329 Cryptosporidium spp. was detected in 9\% and 3\% of samples in La Paz and Kanpur, respectively, at

330 average densities ranging from 9.3 to $560 \mathrm{gc} / \mathrm{m}^{3} .{ }^{44}$

332 The results of this review should be considered alongside a number of important limitations. First, though

333 we used a double-blind search strategy and agreed a priori on inclusion criteria and other methods, bias or

334 human error may have introduced some inconsistency in including literature for the review. Though we

335 used a consensus-based approach to inclusion of studies, we may have missed or mischaracterized

336 individual studies given the large number of papers we reviewed. Second, we excluded studies that were

337 not translatable to English or that had non-extractable data that may have been valuable contributions

338 within this scope of work. Third, because of the broad range of analysis methods, diagnostic tools, and

339 variability in interpretation of data, we did not perform a structured meta-analysis and limited our results

340 and discussion to a broad characterization and categorization of the literature. Future reviews of an

341 expanded number of papers may be able to quantitatively synthesize and compare study findings

342 according to methods and metadata using robust statistical methods well suited to meta-analysis.

\section{$344 \quad 5.0$ CONCLUSION}

345 Based on our interpretation of the results of this review, we can offer the following conclusions. First, 346 enteric microbes and AR are widely detected in outdoor urban aerosols. A wide range of targets have 347 been detected, though bacteria are most prominent; most analytical methods in the studies covered in this 
review employed methods that limited detection to bacteria only. Further attention on specific pathogens of interest and especially studies targeting enteric viruses and protozoa are needed. Second, we observe major gaps in evidence around microbial viability and quantitative estimation of specific enteric

351 pathogens of global risk relevance. Quantitative data are needed alongside aerosol size data to advance

352 fate and transport modeling, and viability of pathogens - even if indirect via bacterial indicator co-culture

353 - is critically important to any assessment of the public health relevance of pathogen detection in

354 aerosols. Third, we can conclude that important gaps in evidence are apparent specifically in settings

355 where the risks of enteric pathogen exposure and AR emergence and spread are most acute: cities of

356 LMICs, which are characterized in part by poor sanitation and high population density in close proximity

357 to potential sources of bioaerosols containing enteric targets. We propose that future studies should

358 address these gaps so that we will be able to better understand the potential for enteric microbes and AR

359 in aerosols to impact global public health and to inform control strategies that can limit exposures when

360 and where they are most critical.

\subsection{CONTRIBUTIONS}

363 Olivia Ginn: Conceptualization, Methodology, Formal analysis, Literature Search, Data Curation and

364 Verification, Writing- Original Draft, Writing- Review and Editing, Visualization, Supervision, Project

365 Administration

366 Sarah Lowry: Methodology, Formal Analysis, Literature Search, Data Curation and Verification,

367 Writing- Original Draft, Writing- Review and Editing

368 Joe Brown: Conceptualization, Methodology, Formal Analysis, Data Verification, Writing- Review and

369 Editing, Funding Acquisition

\section{$371 \quad 7.0$ CONFLICTS OF INTEREST}

372 The authors declare no conflicts of interest. 
medRxiv preprint doi: https://doi.org/10.1101/2021.10.26.21265483; this version posted February 10, 2022. The copyright holder for this preprint (which was not certified by peer review) is the author/funder, who has granted medRxiv a license to display the preprint in perpetuity.

All rights reserved. No reuse allowed without permission.

\subsection{FUNDING}

375 This study was funded by the National Science Foundation under grant number 1653226. This funding

376 source had no role in the design of this study and had no role during its execution, analyses, interpretation

377 of the data, or decision to submit results

378

$379 \quad 9.0$ REFERENCES

3801 Fannin KF, Vana SC, Jakubowski W. Effect of an Activated Sludge Wastewater Treatment Plant 381 on Ambient Air Densities of Aerosols Containing Bacteria and Viruses. Appl Environ Microbiol

$382 \quad 1985 ; 49: 1191-6$.

3832 Benami M, Busgang A, Gillor O, Gross A. Quantification and risks associated with bacterial aerosols near domestic greywater-treatment systems. Sci Total Environ 2016; 562: 344-52.

3853 Sawyer B, Rao KC, O’Brien P, Elenbogen G, Zenz DR, Lue-Hing C. Changes in bacterial aerosols 386 with height above aeration tanks. J. Environ. Eng. 1996; 122. DOI:10.1061/(ASCE)0733$3879372(1996) 122: 5(368)$

3884 Vermeulen LC, Brandsema PS, Kassteele J Van De, et al. Atmospheric dispersion and 389 transmission of Legionella from wastewater treatment plants : A 6-year case-control study. Int J $390 \quad$ Hyg Environ Health 2021; 237. DOI:10.1016/j.ijheh.2021.113811.

3915 Lin K, Marr LC. Aerosolization of Ebola Virus Surrogates in Wastewater Systems. Environ Sci $392 \quad$ Technol 2017; 51: 2669-75.

3936 Sánchez-Monedero MA, Aguilar MI, Fenoll R, Roig A. Effect of the aeration system on the levels 394 of airborne microorganisms generated at wastewater treatment plants. Water Res 2008; 42: 373939544.

3967 Gangamma S, Patil RS, Mukherji S. Characterization and proinflammatory response of airborne 397 biological particles from wastewater treatment plants. Environ Sci Technol 2011; 45: 3282-7.

$398 \quad 8$ Lue-Hing C, Zenz DR, Sedita SJ. Environmental Impact of the Microbial Aerosol Emissions From $399 \quad$ Wastewater Treatment Plants. Water Sci Technol 1982; 14: 289-309. 
9 Cronholm LS. Potential Health Hazards from Microbial Aerosols in Densely Populated Urban Regions Potential Health Hazards from Microbial Aerosols in Densely Populated Urban Regions. Appl Environ Microbiol 1980; 39: 6-12.

40310 Heinonen-Tanski H, Reponen T, Koivunen J. Airborne enteric coliphages and bacteria in sewage $404 \quad$ treatment plants. Water Res 2009; 43: 2558-66.

40511 Paez-Rubio T, Viau E, Romero-Hernandez S, Peccia J. Source bioaerosol concentration and rRNA 406 gene-based identification of microorganisms aerosolized at a flood irrigation wastewater reuse $407 \quad$ site. Appl Environ Microbiol 2005; 71: 804-10.

40812 Sawyer B, Elenbogen G, Rao KC, O’Brien P, Zenz DR, Lue-Hing C. Bacterial aerosol emission rates from municipal wastewater aeration tanks. Appl Environ Microbiol 1993; 59: 3183-6.

Dungan RS. Estimation of infectious risks in residential populations exposed to airborne pathogens during center pivot irrigation of dairy wastewaters. Environ Sci Technol 2014; 48: $5033-42$.

413 Tanner BD, Brooks JP, Gerba CP, Haas CN, Josephson KL, Pepper IL. Estimated Occupational

41615 Viau E, Bibby K, Paez-Rubio T, Peccia J. Toward a consensus view on the infectious risks associated with land application of sewage sludge. Environ Sci Technol 2011; 45: 5459-69.

41816 Paez-Rubio T, Ramarui A, Sommer J, Xin H, Anderson J, Peccia J. Emission rates and characterization of aerosols produced during the spreading of dewatered class B biosolids. Environ Sci Technol 2007; 41: 3537-44.

42117 Pillai SD. Bioaerosols from Land-Applied Biosolids: Issues and Needs. Water Environ Res 2007; $422 \quad 79: 270-8$.

42318 Brooks JP, Tanner BD, Josephson KL, Gerba CP, Haas CN, Pepper IL. A national study on the 424 residential impact of biological aerosols from the land application of biosolids. $J$ Appl Microbiol $425 \quad 2005 ; 99: 310-22$. 
42619 Brooks JP, Gerba CP, Pepper IL. Diversity of aerosolized bacteria during land application of biosolids. J Appl Microbiol 2007; 103: 1779-90.

42820 Brooks JP, Tanner BD, Gerba CP, Haas CN, Pepper IL. Estimation of bioaerosol risk of infection 429 to residents adjacent to a land applied biosolids site using an empirically derived transport model. $430 \quad J$ Appl Microbiol 2005; 98: 397-405.

43121 Baertsch C, Paez-Rubio T, Viau E, Peccia J. Source tracking aerosols released from land-applied 432 class B biosolids during high-wind events. Appl Environ Microbiol 2007; 73: 4522-31.

43322 Shuval HI, Guttman-Bass N, Applebaum J, Fattal B. Aerosolized enteric bacteria and viruses generated by spray irrigation of wastewater. Water Sci Technol 1989; 21: 131-5.

Teltsch B, Katzenelson E. Airborne enteric bacteria and viruses from spray irrigation with wastewater. Appl Environ Microbiol 1978; 35: 290-6.

Pankhurst LJ, Akeel U, Hewson C, et al. Understanding and mitigating the challenge of bioaerosol emissions from urban community composting. Atmos Environ 2011; 45: 85-93.

43925 Pahari AK, Dasgupta D, Patil RS, Mukherji S. Emission of bacterial bioaerosols from a composting facility in Maharashtra, India. Waste Manag 2016; 53: 22-31.

44126 Gao X, Shao M, Luo Y, et al. Airborne bacterial contaminations in typical Chinese wet market $442 \quad$ with live poultry trade. Sci Total Environ 2016; 572: 681-7.

44327 Fang Z, Wang X, Hu L, Ouyang Z, Zheng H. Culturable Airborne Bacteria in Outdoor Environments in Beijing, China [electronic resource]. Microb Ecol 2007; 54: 487-96.

44528 Gangamma S. Characteristics of airborne bacteria in Mumbai urban environment. Sci Total $446 \quad$ Environ 2014; 488-489: 70-4.

44729 Frączek K, Rózycki H, Ropek D. Statistical analyses of bioaerosol concentration at municipal $448 \quad$ landfill site. Ecol Chem Eng S 2014; 21: 229-43.

44930 Huang CY, Lee CC, Li FC, Ma YP, Su HJJ. The seasonal distribution of bioaerosols in municipal $450 \quad$ landfill sites: A 3-yr study. Atmos Environ 2002; 36: 4385-95.

45131 Green CF, Gibbs SG, Tarwater PM, Mota LC, Scarpino P V. Bacterial plume emanating from the 
air surrounding swine confinement operations. J Occup Environ Hyg 2006; 3: 9-15.

$453 \quad 32$ Ko G, Simmons III OD, Likirdopulos CA, Worley-Davis L, Williams M, Sobsey MD.

454 Investigation of Bioaerosols Released from Swine Farms using Conventional and Alternative

$455 \quad$ Waste Treatment and Management Technologies. Environ Sci Technol 2008; 42: 8849-57.

45633 Pillai SD, Ricke SC. Bioaerosols from municipal and animal wastes: background and

457 contemporary issues. Can J Microbiol 2002; 48: 681-96.

45834 Jahne MA, Rogers SW, Holsen TM, Grimberg SJ. Quantitative microbial risk assessment of

459 bioaerosols from a manure application site. Aerobiologia (Bologna) 2015; 31: 73-87.

46035 Rendon RVC, Garcia BCB, Vital PG. Assessment of airborne bacteria in selected occupational

461 environments in Quezon City, Philippines. Arch Environ Occup Heal 2017; 72: 178-83.

46236 Yang K, Li L, Wang Y, Xue S, Han Y, Liu J. Airborne bacteria in a wastewater treatment plant:

463 emission characterization, source analysis and health risk assessment. Water Res 2019; 149: 596-

464606.

46537 Mukherjee A, Duttagupta S, Chattopadhyay S, et al. Impact of sanitation and socio-economy on

466 groundwater fecal pollution and human health towards achieving sustainable development

467 goals across India from ground-observations and satellite-derived nightlight. Sci Rep 2019; 9: 1-

$468 \quad 11$.

46938 Berendes DM, Kirby AE, Clennon JA, et al. Urban sanitation coverage and environmental fecal

470 contamination: Links between the household and public environments of Accra, Ghana. PLoS One

$471 \quad 2018 ; 13: 1-19$.

47239 Wagner EG, Lanoix JN. Excreta Disposal for Rural Areas and Small Communities. World Health $473 \quad$ Organization, 1958.

$474 \quad 40$ Torres NF, Chibi B, Kuupiel D, Solomon VP, Mashamba-Thompson TP, Middleton LE. The use 475 of non-prescribed antibiotics; prevalence estimates in low-and-middle-income countries. A

$476 \quad$ systematic review and meta-analysis. Arch Public Heal 2021; 79: 1-15.

47741 Johnson A, Ginn O, Bivins A, Rocha-Melogno L, Tripathi SN, Brown J. Extended-spectrum beta- 
lactamase (ESBL)-positive Escherichia coli presence in urban aquatic environments in Kanpur, India. J Water Health 2020; 18: 849-54.

48042 Salazar D, Ginn O, Brown J, Soria F, Garvizu C. Assessment of antibiotic resistant coliforms from 481 bioaerosol samples collected above a sewage-polluted river in La Paz, Bolivia. Int J Hyg Environ $482 \quad$ Health 2020; 228: 113494.

$483 \quad 43$ Farling S, Rogers T, Knee JS, Tilley EA, Brown J, Deshusses MA. Bioaerosol emissions $484 \quad$ associated with pit latrine emptying operations. Sci Total Environ 2019; 648: 1082-6.

48544 Ginn O, Rocha-Melogno L, Bivins A, et al. Detection and Quantification of Enteric Pathogens in Aerosols Near Open Wastewater Canals in Cities with Poor Sanitation. Environ Sci Technol 2021. DOI:10.1021/acs.est.1c05060.

Balderrama-Carmona AP, Gortáres-Moroyoqui P, Álvarez-Valencia LH, et al. Occurrence and quantitative microbial risk assessment of Cryptosporidium and Giardia in soil and air samples. Int J Infect Dis 2014; 26: 123-7. meta-analyses: The PRISMA statement. BMJ 2009; 339: 332-6.

Penakalapati G, Swarthout J, Delahoy MJ, et al. Exposure to Animal Feces and Human Health: A

50151 Li J, Cao J, Zhu YG, et al. Global Survey of Antibiotic Resistance Genes in Air. Environ Sci

$502 \quad$ Technol 2018; 52: 10975-84.

50352 Gao M, Qiu T, Sun Y, Wang X. The abundance and diversity of antibiotic resistance genes in the 
atmospheric environment of composting plants. Environ Int 2018; 116: 229-38.

Yasin YM, Kerr MS, Wong CA, Bélanger CH. Factors affecting nurses' job satisfaction in rural and urban acute care settings: A PRISMA systematic review. $J$ Adv Nurs 2020; 76: 963-79.

Gao J-F, Fan X-Y, Li H-Y, Pan K-L. Airborne Bacterial Communities of PM2.5 in BeijingAEROSOL AIR Qual Res 2017; 17: 788-98. Markets andthe Detection of Endotoxin. Front Microbiol 2017; 8.

DOI:10.3389/fmicb.2017.00551. High-tech District in Tai'an City. J Agric Sci 2010; 2: 2008-10.

52360 Cao C, Jiang W, Wang B, et al. Inhalable microorganisms in Beijing's PM2.5 and PM10

524 pollutants during a severe smog event. Environ Sci Technol 2014; 48: 1499-507.

52561 Bertolini V, Innocente E, Rampazzo G, et al. Temporal variability and effect of environmental

526 variables on airborne bacterial communities in an urban area of Northern Italy [electronic

527 resource]. Appl Microbiol Biotechnol 2013; 97: 6561-70.

52862 Bowers RM, McLetchie S, Knight R, Fierer N. Spatial variability in airborne bacterial 
source environments. ISME J 2011; 5: 601-12.

53163 Fang Z, Guo W, Zhang J, Lou X. Influence of heat events on the composition of airborne bacterial communities in urban ecosystems. Int J Environ Res Public Health 2018; 15. DOI:10.3390/ijerph15102295.

53464 Gandolfi I, Bertolini V, Bestetti G, et al. Spatio-temporal variability of airborne bacterial 535 communities and their correlation with particulate matter chemical composition across two urban 536 areas. Appl Microbiol Biotechnol 2015; 99: 4867-77.

53765 Jang G Il, Hwang CY, Cho BC. Effects of heavy rainfall on the composition of airborne bacterial communities. Front Environ Sci Eng 2018; 12: 1-10.

Ouyang W, Gao B, Cheng H, et al. Airborne bacterial communities and antibiotic resistance gene dynamicsin PM2.5 during rainfall. Environ Int 2020; 134. DOI:10.1016/j.envint.2019.105318. 11.

54468 Zhen Q, Deng Y, Wang Y, et al. Meteorological factors had more impact on airborne bacterial communities than air pollutants. Sci Total Environ 2017; 601-602: 703-12.

Brodie EL, DeSantis TZ, Parker JPM, Zubietta IX, Piceno YM, Andersen GL. Urban aerosols harbor diverse and dynamic bacterial populations. Proc Natl Acad Sci 2007; 104: 299-304.

55171 Mhuireach G, Betancourt-Román CM, Green JL, Johnson BR. Spatiotemporal controls on the 552 urban aerobiome. Front Ecol Evol 2019; 7. DOI:10.3389/fevo.2019.00043.

55372 Serrano-Silva N, Calderon-Ezquerro MC. Metagenomic survey of bacterial diversity in the 554 atmosphere of Mexico City using different sampling methods. Environ Pollut 2018; 235: $20-9$.

55573 Franzetti A, Gandolfi I, Gaspari E, Ambrosini R, Bestetti G. Seasonal variability of bacteria in fine 
and coarse urban air particulate matter. Appl Microbiol Biotechnol 2011; 90: 745-53.

$557 \quad 74$ Fierer N, Liu Z, Rodríguez-Hernández M, Knight R, Henn M, Hernandez MT. Short-term temporal variability in airborne bacterial and fungal populations. Appl Environ Microbiol 2008; 74: $200-7$.

56075 Fan C, Li Y, Liu P, et al. Characteristics of airborne opportunistic pathogenic bacteria during $561 \quad$ autumn and winter in Xi'an, China. Sci Total Environ 2019; 672: 834-45.

56276 Fykse EM, Tjärnhage T, Humppi T, et al. Identification of airborne bacteria by 16S rDNA 563 sequencing, MALDI-TOF MS and the MIDI microbial identification system. Aerobiologia (Bologna) 2015; 31: 271-81.

Gat D, Mazar Y, Cytryn E, Rudich Y. Origin-Dependent Variations in the Atmospheric Microbiome Community in Eastern Mediterranean Dust Storms. Environ Sci Technol 2017; 51: 6709-18.

Gou H, Lu J, Li S, Tong Y, Xie C, Zheng X. Assessment of microbial communities in PM1 and PM10 of Urumqi during winter. Environ Pollut 2016; 214: 202-10.

$57380 \quad$ Hurtado L, Rodriguez G, Lopez J, et al. Characterization of atmospheric bioaerosols at 9 sites in Tijuana, Mexico. Atmos Environ 2014; 96: 430-6.

57581 Innocente E, Franzetti A, Facca C, et al. Influence of seasonality, air mass origin and particulate 576 matter chemical composition on airborne bacterial community structure in the Po Valley, Italy. Sci $577 \quad$ Total Environ 2017; 593-594: 677-87.

$578 \quad 82$ García-Mena J, Murugesan S, Pérez-Muñoz AA, et al. Airborne Bacterial Diversity from the Low $579 \quad$ Atmosphere of Greater Mexico City. Microb Ecol 2016; 72: 70-84.

58083 Li H, Zhou X-Y, Yang X-R, Zhu Y-G, Hong Y-W, Su J-Q. Spatial and seasonal variation of the airborne microbiome in a rapidly developing city of China. Sci Total Environ 2019; 665: 61-8. 
84 Liang Z, Yu Y, Ye Z, Li G, Wang W, An T. Pollution profiles of antibiotic resistance genes associated with airborne opportunistic pathogens from typical area, Pearl River Estuary and their exposure risk to human. Environ Int 2020; 143: 105934.

Abd Aziz A, Lee K, Park B, et al. Comparative study of the airborne microbial communities and their functional composition in fine particulate matter (PM2.5) under non-extreme and extreme PM2.5 conditions. Atmos Environ 2018; 194: 82-92.

Lu Z, Liu Q, Xiong Y, Huang F, Zhou J, Schauer JJ. A hybrid source apportionment strategy using positive matrix factorization (PMF) and molecular marker chemical mass balance (MM-CMB) models. Environ Pollut 2018; 238: 39-51. mountainous area and the urban areas. Atmos Res 2020; 231. https://dx.doi.org/10.1016/j.atmosres.2019.104676. eukaryotic diversity in the urban air of Madrid (Spain). Atmos Environ 2019; published online Sept 8. https://dx.doi.org/10.1016/j.atmosenv.2019.116972.

601

Romano S, Becagli S, Lucarelli F, Rispoli G, Perrone MR. Airborne bacteria structure and

60391 Shen F, Zheng Y, Niu M, et al. Characteristics of biological particulate matters at urban and rural $604 \quad$ sites in the North China Plain. Environ Pollut 2019; 253: 569-77.

60592 Soleimani Z, Sorooshian A, Goudarzi G, Maleki H, Marzouni MB. Impact of Middle Eastern dust 606 storms on indoor and outdoor composition of bioaerosol. Atmos Environ 2016; 138: 135-43.

60793 Stewart JD, Shakya KM, Bilinski T, Wilson JW, Ravi S, Choi CS. Variation of near surface 
61094 Sun Y, Xu S, Zheng D, Li J, Tian H, Wang Y. Effects of haze pollution on microbial community changes and correlation with chemical components in atmospheric particulate matter. Sci Total

61395 Wei M, Liu H, Chen J, et al. Effects of aerosol pollution on PM2.5-associated bacteria in typical 614 inland and coastal cities of northern China during the winter heating season. Environ Pollut 2020; 262: 114188 .

Agarwal S, Mandal P, Srivastava A. Quantification and Characterization of Size-segregated Bioaerosols at Municipal Solid Waste Dumping Site in Delhi. Procedia Environ Sci 2016; 35: $400-7$.

Núñez A, Moreno DA. The Differential Vertical Distribution of the Airborne Biological Particles

80: $322-33$. community composition of the near-surface atmosphere in coastal megacity. Aerobiologia (Bologna) 2017; 33: 555-75.

62599 Yan D, Tao Z, Yu L-Y, Su; J, Yu L-Y. Structural Variation in the Bacterial Community Associated with Particulate Matter in Beijing, China During Hazy and Nonhazy Days. Appl Environ Microbiol 2018; 84: 1-13.

631101 Yooseph S, Andrews-Pfannkoch C, Tenney A, et al. A metagenomic framework for the study of 632 airborne microbial communities. PLoS One 2013; 8. DOI:10.1371/journal.pone.0081862.

633102 Zhao Y, Chen Z, Hou J, et al. Monitoring antibiotic resistomes and bacterial microbiomes in the 
aerosols from fine, hazy, and dusty weather in Tianjin, China using a developed high-volume tandem liquid impinging sampler. Sci Total Environ 2020; 731: 139242.

636103 Soto T, Lozano M, Vicente-Soler J, Cansado Vizoso J, Gacto Fernández MJ. Microbiological survey of the aerial contamination in urban areas of the city of Murcia, Spain. An Biol 2009; 31:

639104 Amarloei A, Fazlzadeh M, Jafari AJ, Zarei A, Mazloomi S. Particulate matters and bioaerosols 640 during Middle East dust storms events in Ilam, Iran. Microchem J 2020; 152. DOI:10.1016/j.microc.2019.104280.

105 Cha Y, Park M-H, Lee S-H, Kim JH, Cho KH. Modeling spatiotemporal bacterial variability with meteorological and watershed land-use characteristics. Water Res 2016; 100: 306-15.

106 Cuthbertson L, Amores-Arrocha H, Malard LA, Els N, Sattler B, Pearce DA. Characterisation of arctic bacterial communities in the air above svalbard. Biology (Basel) 2017; 6. DOI:10.3390/biology6020029.

647107 Du P, Du R, Ren W, Lu Z, Fu P. Seasonal variation characteristic of inhalable microbial communities in PM2.5 in Beijing city, China. Sci Total Environ 2018; 610-611: 308-15. PM2.5collected during the 2014 APEC summit periods. Aerosol Air Qual Res 2018; 18: 444-55. in bacteria than fungi and their co-occurrences with ammonia-oxidizing microorganisms in PM2.5. Environ Pollut 2019; 251: 668-80.

654110 Rodriguez-Gomez C, Ramirez-Romero C, Cordoba F, et al. Characterization of culturable airborne microorganisms in the Yucatan Peninsula. Atmos Environ 2020; 223: 117183.

111 Sun X, Li D, Li B, et al. Exploring the disparity of inhalable bacterial communities and antibiotic 659112 Velez-Quinones MA. Study of Airborne Bacterial Populations in Urban Areas Using Phenotypic 
and Phylogenetic Characterization. ProQuest Diss. Theses. 2013.

663113 Zhou Y-W, Lv Y, Chen X, et al. Characteristics of bacterial communities in fine particulate matter 664 of severe cold region, China. Zhongguo Huanjing Kexue/China Environ Sci 2019; 39: 3616-23.

665114 Cao Y, Raith MR, Griffith JF. Droplet digital PCR for simultaneous quantification of general and 666 human-associated fecal indicators for water quality assessment. Water Res 2015; 70: 337-49.

667115 Chen B, Yang Y, Liang X, Yu K, Zhang T, Li X. Metagenomic profiles of antibiotic resistance 668 genes (ARGs) between human impacted estuary and deep ocean sediments. Environ Sci Technol 2013; 47: 12753-60.

Hu Z, Liu H, Zhang H, et al. Temporal discrepancy of airborne total bacteria and pathogenic bacteria between day and night. Environ Res 2020; 186: 109540.

672117 Ji L, Zhang Q, Fu X, et al. Feedback of airborne bacterial consortia to haze pollution with different PM2.5 levels in typical mountainous terrain of Jinan, China. Sci Total Environ 2019; 695: 133912.

674118 Najafi MS, Khoshakhllagh F, Zamanzadeh SM, Shirazi MH, Samadi M, Hajikhani S. Iran. Arab J Geosci 2014; 7: 5367-81.

677119 Woo AC, Brar MS, Chan Y, et al. Temporal variation in airborne microbial populations and microbially-derived allergens in a tropical urban landscape. Atmos Environ 2013; 74: 291-300.

679120 Hudzicki J. Kirby-Bauer disk diffusion susceptibility test protocol. Am Soc Microbiol 2009; : 114.

681121 Karp BE, Tate H, Plumblee JR, et al. National antimicrobial resistance monitoring system: Two decades of advancing public health through integrated surveillance of antimicrobial resistance.

684122 Barraud O, Baclet MC, Denis F, Ploy MC. Quantitative multiplex real-time PCR for detecting class 1, 2 and 3 integrons. J Antimicrob Chemother 2010; 65: 1642-5. 
123 Ma L, Li AD, Yin X Le, Zhang T. The Prevalence of Integrons as the Carrier of Antibiotic Resistance Genes in Natural and Man-Made Environments. Environ Sci Technol 2017; 51: 57218.

124 Mazel D. Integrons: Agents of bacterial evolution. Nat Rev Microbiol 2006; 4: 608-20.

690125 Jones ER, Van Vliet MTH, Qadir M, Bierkens MFP. Country-level and gridded estimates of wastewater production, collection, treatment and reuse. Earth Syst Sci Data 2021; 13: 237-54.

GBD 2017 Causes of Death Collaborators. Global, regional, and national age-sex-specific mortality for 282 causes of death in 195 countries and territories, 1980-2017: a systematic analysis for the Global Burden of Disease Study 2017. Lancet 2018; 392: 1736-88. genomics for public health practice: A scoping review. Implement Sci 2019; 14: 1-16. opportunities. Front Microbiol 2015; 6. DOI:10.3389/fmicb.2015.01027. the microbiome and resistome. Sci Rep 2018; 8: 1-11.

Murray CJ, Ikuta KS, Sharara F, et al. Global burden of bacterial antimicrobial resistance in 2019: a systematic analysis. Lancet 2022; 6736. DOI:10.1016/s0140-6736(21)02724-0.

704131 Taylor SC, Laperriere G, Germain H. Droplet Digital PCR versus qPCR for gene expression analysis with low abundant targets: From variable nonsense to publication quality data. Sci Rep 2017; 7: 1-8.

132 Bagley ST, Auer MT, Stern DA, Babiera MJ. Sources and fate of giardia cysts and cryptosporidium oocysts in surface waters. Lake Reserv Manag 1998; 14: 379-92.

$711 \quad 134$ Medina C, Ginn O, Brown J, et al. Detection and assessment of the antibiotic resistance of 
Enterobacteriaceae recovered from bioaerosols in the Choqueyapu River area, La Paz - Bolivia. Sci Total Environ 2020; : 143340.

714135 Salazar D, Ginn O, Brown J, Soria F, Garvizu C. Assessment of antibiotic resistant coliforms from bioaerosol samples collected above a sewage-polluted river in La Paz, Bolivia. Int J Hyg Environ

717136 Collaborators G 2016 DD. Estimates of the global, regional, and national morbidity, mortality, and 718 aetiologies of diarrhoea in 195 countries: a systematic analysis for the Global Burden of Disease Study 2016. Lancet Infect Dis 2018; 18: 1211-28.

720137 Sanz-García F, Gil-Gil T, Laborda P, Ochoa-Sánchez LE, Martínez JL, Hernando-Amado S. Coming from the wild: Multidrug resistant opportunistic pathogens presenting a primary, not human-linked, environmental habitat. Int J Mol Sci 2021; 22. DOI:10.3390/ijms22158080.

723138 Gerba CP, Betancourt WQ, Kitajima M. How much reduction of virus is needed for recycled water: A continuous changing need for assessment? Water Res 2017; 108: 25-31.

725139 Symonds EM, Griffin DW, Breitbart M. Eukaryotic viruses in wastewater samples from the United States. Appl Environ Microbiol 2009; 75: 1402-9.

727140 Hellmér M, Paxéus N, Magnius L, et al. Detection of pathogenic viruses in sewage provided early warnings of hepatitis A virus and norovirus outbreaks. Appl Environ Microbiol 2014; 80: 677181.

141 Marks PJ, Vipond IB, Regan FM, Wedgwood K, Fey RE, Caul EO. A school outbreak of Norwalk-like virus: Evidence for airborne transmission. Epidemiol Infect 2003; 131: 727-36.

732142 Marks PJ, Vipond IB, Carlisle D, Deakin D, Fey RE, Caul EO. Evidence for airborne transmission 733 of Norwalk-like virus (NLV) in a hotel restaurant. Epidemiol Infect 2000; 124: 481-7.

734143 O’Neill PD, Marks PJ. Bayesian model choice and infection route modelling in an outbreak of $735 \quad$ Norovirus. Stat Med 2005; 24: 2011-24.

736144 Alsved M, Widell A, Dahlin H, Karlson S, Medstrand P, Löndahl J. Aerosolization and recovery of viable murine norovirus in an experimental setup. Sci Rep 2020; 10: 1-10. 
medRxiv preprint doi: https://doi.org/10.1101/2021.10.26.21265483; this version posted February 10, 2022. The copyright holder for this preprint (which was not certified by peer review) is the author/funder, who has granted medRxiv a license to display the preprint in perpetuity.

All rights reserved. No reuse allowed without permission. 